\title{
Research Review on the Basic System of Real Estate Registration
}

\author{
Mengdi Wang \\ Law School, Xiamen University Tan Kah Kee College, Zhangzhou 363105, China \\ jgxy@xujc.com
}

\begin{abstract}
The basic scope of real estate mainly includes connotation of real estate registration errors, the nature of damages and liability forms, the doctrine of liability fixation and other aspects belonging to the registration scope of real estate rights, the types of registration and the false registration system. As for the registration scope of real estate rights, research disputes are centered on land contract management rights, hypothec, stratification of construction land-use right, whether making leasehold a real right should be registered, and how to register and its registration validity; as for registration types, academic research focuses on special registration systems (mainly including correction registration, objection registration and advance notice registration); as for research on systems concerning real estate registration errors, the connotation of real estate registration errors, the nature of damages and liability forms, and the doctrine of liability fixation are the key areas. The systematic organization of the above research helps lay a theoretical foundation for China to formulate a systematic and unified law of real estate registration
\end{abstract}

Keywords: registration system of real estate, registration scope of real estate rights, types of real estate registration, false registration of real estate.

\section{Introduction}

Real estate registration, which refers to the fact that the relevant state registration department records the applicant's real property right and alternations in the real estate register according to his or her application, is a real right system established by China's Real Right Law. The registration system of real estate reflects demonstrative principle of real right, which guarantees the security and order of transactions and maintains a fair and efficient market order by publicizing the state and ownership of real property rights. However, there are many controversies over research on the real estate registration system among the current academic community; and studies of different systems need to be more systematic and unified. In the absence of a unified real estate registration law, a systematic review of existing research is necessary. Therefore, this article will select the basic scope of real estate registration (namely, registration scope, registration types and false registration) as the main line, striving to provide a more comprehensive overview of the results have been made in research on real estate registration.

\section{Registration Scope of Real Estate Rights}

The registration scope of real estate rights mainly includes three types: the first category refers to real estate, such as ownership of buildings and land contract management rights; the second category refers to real rights related to real estate, such as ownership of construction lands, the use right of homestead, and easement; the third category refers to other legal property rights that need to be registered, such as the new forms of wealth which emerge with the development of social economy. According to Article 5 of the Interim Regulations on the Registration of Real Estate, the following real property rights must be registered in line with the regulations: collective land ownership; ownership of buildings and structures such as houses; ownership of forests and trees; land contract management rights such of lands, forest lands and grasslands; the right to use construction lands; the right to use homestead; the right to use the sea; easement; hypothec; and other real property rights required to be registered by law. The academic community has centered research on the registration of real estate rights such as the creation and alternation of land contract management rights, hypothec, the stratification of construction land use rights, and making leasehold a real right. 


\subsection{Creation and Alternation of Land Contract Management Rights}

This section deals with the question of whether creation or alternation of land contract management rights requires registration. At present, the unified creation of China's land registration system including the registration of land contract management rights, which is based on the registration done by the administrative departments of land and resources, is a reasonable choice conforming to the nature of the land contract management rights. Incorporating land contract management rights into the unified registration of lands is a realistic need for the transfer of land contractual management rights, reasons for which are as follows: out of transaction security, registration is required as the only criterion for judging the alternation of real rights when methods like transfer, mortgage and buying shares appearing during the transfer of land contract management rights; incorporating the land contract management rights and other land property rights into the scope of land registration and uniformly issue certificates of these rights are not only conducive to the unification of land rights and the enhancement of the protection of land contract management rights but also help save registration costs and land transaction costs; the unified integration of the land contract management system and the entire land rights system is conducive to touching the deep-seated problems of the real right system, thus rationalizing the entire system of land rights and the land rights management. At present, the registration confrontation doctrine has been adopted as a legislative standard in China's legislation, which has been confirmed by some articles in the Real Right Law. However, with the creation of the registration confrontation system in China's Real Right Law, how to interpret and apply this standard in China's existing legal framework has become a matter of debate. For example, Long Jun [1] proposed the theory of right appearance and the theory of trust protection, trying to construct a Chinese-style registration confrontation based on good faith and acquisition; and he believed that the assignee of first transfer got the full real right while the assignee of the second transfer is able to obtain the real right because of his trust in the right appearance of the assignor. However, Guo Zhijing [2] believed that although this theory had certain rationality in interpretative theory, it actually deviated from the original intention of registration confrontation. In other words, the essence of registration confrontation was to only empower the third party to deny the alternation of property rights by others rather than acquire the real right himself. Therefore, the "no registration, no confrontation" rule was the result of a balance between ensuring the convenience of transactions and protecting the interest of the third party, which served to remind the parties of risks and reduced investigation obligations of the third party. Therefore, the theoretical structure of China's registration confrontation should adhere to the theory of the third party [3], and the goodwill of the third party should be magnified.

In addition, there is another question of whether the creation and alternation of land contract management rights should be registered, that is, the registration validity of the creation and alternation of land contract management rights. Ren Qingen [4] believed that the creation and registration of rural land contract management rights and the transfer and exchange registration of rural land contract management rights should adopt the doctrine of registration validity, namely, creditor formalism. According to Article 14 of the Real Right Law, when the parties agree on the creation and transfer meaning of land real estate rights, there appears only the debt validity. Only when the registration of the real estate rights is added can the effect of the property rights alternation be produced. In addition, the doctrine of registration validity of real estate also applies to the creation and alternation of land real rights, such as land use rights, land mortgage rights, and house ownerships. However, China has adopted the doctrine of registration confrontation in the field of real right law, that is, the concensualism [5]. This view holds that once the party expresses the meaning of changing property rights, the legal effect of the alternation of property rights appears. Unregistered property rights can also be established through the consent of the parties, but the property rights alternation cannot confront against a bona fide third party before legal registration, that is, not registering against a bona fide third party without registration.

As for the transfer of before the registration, there are also contradictions in the changing patterns of property rights. Item 1 of Article 127 of the Real Right Law stipulates: "The land contract management right is established when the land contracting management right contract comes into 
effect." The general theory [6] believes that this provision actually adopts real right alteration mode featuring concensualism to deal with the land contract management right. In other words, the creation of land contract management rights only needs to be agreed between the client and the contractor; and the law does not require the creation of the real right to be registered. Xing Lin [7] believed that the creation and alternation of rural land contract management rights adopts a registration validity mode. Whether rural land management contracting rights are obtained by household contracting or by other means, the acquisition and alternation of rights should adopt the registration validity mode, that is, the acquisition and alternation of rural land contract management rights are not valid without confirmation and registration. Shen Weixing [8] believed that the household contracting method was uniformly registered by the local people's government at or above the county level, and other contracting methods were registered according to the party's application.

\subsection{Mortgage Registration}

The advance notice mortgage registration commercial housing is derived from the advance notice registration system. The provision of Article 20 of the Real Right Law stipulates that in case the related parties entered into a purchase agreement on a premise or the real right of any other realty, they may apply for advance notice registration to the registration organ so as to ensure the realization of the real right in the future. In China's real right law, the advance notice registration system is an auxiliary system, which is aimed to cooperate with the alternation of real rights to ensure the realization of its validity. Once generated, it can exclude the third party from exercising his right to the property.

As for the question of whether advance notice registration applies to the mortgage of pre-purchased commercial housing, Zhang Shuangen [9] believed the answer was negative. This was because although the advance notice registration system of Article 20 of the Real Right Law was considered to be mainly applicable to the pre-sale of commercial housing in the legislation, practice and theoretical views, the structure of the advance notice registration was not complete in terms of system and requirements in the case of commercial housing pre-sale, especially the lack of object requirements. Under the current law, it is difficult to overcome these shortcomings and regard the pre-sale of commercial housing as the normative presupposition of the advance notice registration system, which is a mistake in the process of China's "Real Right Law" following the German law and should be corrected. He also proposed that the existing real estate register was a constructive lever for the advance notice registration system. If there was no real estate register, then discussing the use of the register would be impossible and the advance notice registration would lose its structural foundation accordingly. In other words, in the case of commercial housing pre-sale, once a corresponding existing real estate register was absent, the advance notice registration, a type of real estate registration, would lack the technical lever contributing to its construction, thus becoming impossible.

Cheng Xiao expressed opposition to this view [10]. He believed that the conditions of use in German law could not be used to deny the possibility of China's advance notice registration applying to the pre-purchase of commercial housing and the mortgage of pre-purchased commercial housing. The specific reasons for this view were as follows. First, Item 3 of Article 2 of China's Real Property Law of China explicitly recognized the specific principle of property rights, namely, the object of property rights must be a single, specific object. Although the commercial premises used by the developer for pre-sales had not yet been built (including being built or not yet available), they were not unspecified or undetermined. Therefore, the absence of the transaction object could not be used as a reason for negating the applicability of advance notice registration to the pre-purchase of commercial housing and the mortgage of pre-purchased commodity housing. Second, the alternation of property rights in our country's law was caused by a contract entered into by the related parties concerned on the creation, alteration, alienation or termination of the real right and the statutory publicity method (delivery or registration) rather than disciplinary actions. Therefore, when China applied the advance notice registration to pre-purchased commercial housing and its mortgage rights, it may not consider the issue of the specific principle. Moreover, in practice, only the buyer who had 
applied for the advance notice registration had the right to request the seller to actually perform the contract. By clarifying the applicability of advance notice registration to the pre-sale of commercial housing and the mortgage pre-purchased of commercial housing, it could effectively solve the disputes of "one house being sold to many people" involved by real estate development enterprises in the judicial practice. Third, in China, there was no such a technical obstacle that the advance notice registration of pre-purchased commercial housing and the pre-purchased commercial housing mortgage rights was done without registration books. Although the pre-purchased commercial housing had not been legally constructed and it was impossible to set up a housing registration book, the real estate management department would record each pre-sale of commercial housing by establishing a pre-sales real estate form which was essentially a "pre-registration book" and registered the pre-sale situation, right, transaction, and restrictions of each commercial house. Therefore, the real estate form was equivalent to the real estate registration book in nature, and their contents were almost the same. In summary, Cheng Xiao believed that from the perspective of legislation and reality, regulations of the advance notice registration were applicable to the advance notice registration of both pre-purchased commercial housing and its mortgage rights.

There are two views on the nature of the mortgage registration of buildings under construction. The first point of view advocates the theory of advance notice registration [11] based on Article 30 of the Real Right Law which stipulates that the relevant parties can only obtain the ownership and apply for the first registration of the ownership of the house after the construction of this house is legally completed. While the mortgage right of house can only be acquired after the house is built and the first registration of ownership is completed. Therefore, registration for the mortgage of the building under construction can only be done in accordance with Article 20 of the Real Right Law. The second view refers to the theory of official registration [12] which believes that the mortgage registration of houses under construction is the same as the mortgage registration of houses in nature. In other words, both of them belong to official registration instead of advance notice registration. From Article 47 of the Interpretation of the Guaranty Law which stipulates that "the people's court may determine that the mortgage is valid if the house or other building that has not been built or is under construction is mortgaged in line with the law and the party has finished the registration of the mortgaged property" and Article 187 of the Real Right Law which stipulates that "in case properties as provided for in Items (1), (2) and (3) of Paragraph 1 of Article 180 in the present Law or a building under construction in Item (5) are mortgaged, the mortgage registration shall be gone through, and such mortgage right shall be established as of the date of registration", it can be seen that the creditor obtains the mortgage right after finishing the mortgage registration of the house under construction.

\subsection{Stratification of Construction Land-use Right}

The section deals with registration issues concerning the stratification of construction land-use right. Shi Jianhui [13] believed that as a type of usufructuary right, the acquisition, alternation and termination of stratified use rights of construction lands need to go through the corresponding registration procedures. In addition, since the construction lands for stratified use can overlap on the projection surface and spatially intersect, and do not like other ordinary lands which are intuitive and extremely exclusive within a single surface space and can be developed for multi-levels at different periods according to different scopes, their registration should include their development and utilization in all the four directions and the state of their usufructuary rights in the upper and lower space of the lands. Data recording should be based on the three-dimensional space and even consider the timing of using the tiered use rights of construction lands at different levels so as to avoid damaging the interest of the previous holder of the usufructuary rights. Wang Yanxia believed that [14] when registering land rights, we should be dispersing the scope of the specific division decision layer. The planning department should fully consider the relevant factors and unify the standards of the division level which not only facilitates the orderly and reasonable overall planning of the city and more reasonable collection of land transfer fees, but also demonstrates efficient use of lands and space. 


\subsection{Making Leasehold a Real Right}

The section deals with the question of whether making leasehold a real right should be registered and what its effectiveness is. The doctrine of registration confrontation [15] believes that although the leasehold demonstrates the nature of credit, when such a right is set for real estate, the lessee actually acquires the right the control which demonstrates the nature of property right because the leasehold is transformed into a real right. When there is an alternation in the real right, the leasehold and the alternation of the real right are confronting each other, and thus the confrontation problem arises. Without registration, the lessee shall not confront the third party. The Doctrine of possession confrontation [16] believes that in the alternation of property rights, the trust of the fairness of the register is protected by law so that the assignee or the right acquirer knows the status of the right; and the registration is the publicity of the status quo of the property right. In this way, those who actually give the object to others to exercise right are treated as a possessor, which is a reasonable choice made based on balancing the interests of the tenant and the third party without affecting the security of real estate transaction. China has determined that the leasehold has the protest power in the Contract Law. Since Article 299 of the Contract Law lacks regulations on the publicity mechanism of the protest power of leasehold, we should consider making delivery and possession as the important requirements even if the leasehold registration is not adopted.

\section{Types of Real Estate Registration}

Real estate registration can be divided into basic types and special types. The former includes initial registration, alternation registration, transfer registration and cancellation registration, while the latter includes correction registration, objection registration, advance notice registration and sequestration registration. The study of special types of real estate registration (such as advance notice registration and correction registration) has always been concerned by the academic community and is reviewed as follows.

\subsection{Correction Registration}

Correction registration refers to the registration done by the registration agency in accordance with the application of the party or its duty and power to eliminate the error in the real estate register. Item 1 of Article 19 of China's Real Right Law clearly stipulates that "In case any right holder or interested party holds that there is anything wrong in any item recorded in the realty register, it/he may apply for a correction of the registration. The registration organ shall revise the registration accordingly, in case the holder recorded in the realty register agrees to revise the registration in written form or there is evidence to prove that the registration is wrong." Here, the first issue involves the scope of correction registration, which is related to the meaning of false registration of real estate will be discussed below.

This section deals with the issue concerning the nature of the claim on correcting registration. The claim on correction registration, which is essentially a real property right and reflects that the right to confront third-party's effect is protected, is a claim based on absolute rights. There are different theoretical views on the nature of the claim on correction registration: First, the theory of claim on real right [17] believes that the claim for registration is essentially a kind of right derived from the real right of the very object enjoyed by the right holder, or specifically, a claim on excluding damages. A party whose rights have been impaired by false registration may file a lawsuit for the person who was wrongly registered in the register and require correction registration. Therefore this claim features the "property of preservation". Second, the theory of claim on credit believes that the registration request should include the claim on correction registration. Wang Liming [18] believed that, the parties did not enjoy legal property rights until they completed the registration requirements, so the nature of the claim on correction registration was not a claim on real right. This view strictly regarded registering the alternation of the real property right as a necessity and believed that the alternation of property rights occurred as long as the registration was carried out but the alternation did not occur if there was no registration. This practice of making registration as the only criterion 
did not meet the purpose of legislation. Shen Huiwen [19] believed that, according to the provisions of Articles 129 and 158 of the China's Real Right Law, the registration confrontation mode was adopted for registering real property rights such as the alternation of land contract management rights and easement. Where there were errors in real estate registration and the real right of the right holder was infringed, the claim on excluding the nuisance was justifiable. Therefore, the request for correction registration belonged to the real right claim.

As for the question of whether the correction registration is ex officio or based on the application for registration, Cheng Xiao [20] believed that, as China's Real Right Law did not clearly stipulate that the registration done by the registration authority should be ex officio, the registration department could make correction registration according to the authority and didn't need to require strict conditions when making correction registration according to the application of the party. For example, Article 75 of the Registration of Housing stipulates: "In case the registration department finds errors which don't involve the ownership and content of the real property right in the housing registration book, it shall notify the relevant right holder in writing to correct the registration within the prescribed time limit; if the right holder does not complete correction registration within the prescribe time limit without justified reasons, the registration department may correct the record of the housing register according to the application materials for registration or valid legal documents and notify the relevant party in writing." Yin Fei [21] believed that, in case the real property right was altered due to a legal fact, the relevant parties should first apply to the registration agency, and then the registration agency would review and confirm whether the legal fact was justified, and finally determine to agree to or refuse registration. Therefore, he believed that the nature of real estate registration was administrative confirmation, and the correction registration should be based on the application and supplemented by the authority's power.

\subsection{Objection Registration.}

Item 2 of Article 19 of the Real Right Law stipulates that: "The interested party may apply for dissidence registration, in case the holder recorded in the realty register does not agree to the alteration. Where the registration organ grants the dissidence registration but the applicant fails to lodge an action within 15 days as of the date of dissidence registration, the dissidence registration shall lose its effect. In case the dissidence registration is improper and bring into damages to the right holder, the holder may require the applicant to compensate for damages." As for the applicability of the objection registration, it is necessary for the subject applying for objection registration to explain to the interested parties in detail. The subject should explain to the rights holders whose rights are restricted due to errors in the real estate register and cannot be repaired through correction registration and the real estate registration agency which is subject to ex officio registration if necessary. The objection registration includes the objection registration of ownership and other property rights.

This section deals with the question of whether the interested parties include the right holder and the real estate registration agency. Chen Ye [22] believed that the interested parties applying for objection registration should include the registered right holder, namely, the person who had the right to claim the registered real property right. However, according to Item 2 of Article 1 of the Real Right Law, the scope of the interested parties seems to exclude the possibility of the registration right holder applying for objection registration. Sun Xianzhong [23] agreed that the real estate registration agency could carry out ex officio objection registration because it was conducive to changing the passive position of the registration authority when taking responsibility for registration errors. Besides, from the perspective of fully protecting the real right holder, it would also cause the third party to obtain the real property in good faith when the registration authority found that the registration is obviously false with sufficient evidence but couldn't take certain measures to correct it in time. Since the real estate registration agency was allowed to carry out correction registration, it should be permitted to take the initiative to deal with objection registration if necessary without affecting the right of the registered right holder. Therefore, the understanding of interested parties should not be limited to the subjects that could claim property rights of registered real estate. Instead, it should also include subjects having direct interests. In other words, the understanding of interested parties should be 
expanded to include both the registered real right holders whose rights were restricted but cannot be recovered by registration and the registration agency which eliminated the risk of liability for damages due to registration errors by carrying out ex officio objection registration.

There still exists controversy over the question of whether the objection registration has the effect of restricting the registered right holder to dispose of his real property rights among the academic community. Sun Xianzhong [24] believed that the objection registration had the effect of restricting the registered right holder to dispose of the real property rights and that the "property, unclear or undisclosed property shall not be mortgaged" stipulated in Article 184 of the Real Right Law shall be made applicable to the objection registration. In addition, if a person had no right to dispose of the property, the registration agency shall suspend the disposition registration. Since the registered right holders or the rights recorded in the register may be wrong or insufficient, the interests of the actual right holders might be harmed and if the registered right holders were allowed dispose of their rights, thereby generating series of problems such as real estate returns. Chang Pengao [25] believed that the registered right holder was not deprived of or restricted from his right to dispose of the real property after objection registration, so the registration agency shall suspend the transfer registration during the process of objection registration. As for the objection registration applied by both parties, he held that the registered right holder had the right to dispose of the property. While once the registered right holder was corrected as a non-real right holder, his disposition right became invalid. This act did not take effect without the confirmation made by the actual right holder. Yu Haiyong [26] believed that objection registration did not exert a restriction on the right holder's disposing of his real property rights. Instead, objection registration only broke the credibility of the register and avoided others' bona fide acquisition. In other words, it only objectively affected the parties' willingness to trade. The objection registration not only indicated that the registered right may be untrue, but also suggested a situation in which the registered may be true and was based on the correctness and credibility of the real property register, and thus couldn't deny the disposition right of the registered right holder. In other words, the registered right holder could still exercise his rights in accordance with the register without restrictions. It was also conducive to improving transaction efficiency if there was no need to restrict disposition rights, thus achieving a balance among the nominal registrant, the actual right holder, the third party and society as a whole.

\subsection{Advance Notice Registration}

Article 20 of the Real Right Law of China stipulates: "In case the related parties entered into a purchase agreement on a premise or the real right of any other realty, they may apply for advance notice registration to the registration organ so as to ensure the realization of the real right in the future. Without the consent of the holder in the advance notice registration, any disposal of the realty, after the advance notice registration, may not produce effect of real right. In case the obligee's right is terminated after the advance notice registration is made, or the application for the registration of the realty is not filed within 3 months as of the date when it can be registered, the advance notice registration shall lose its effect."

Domestic scholars' arguments over the nature of advance notice registration can be summarized into the following three viewpoints. The first viewpoint regards the nature of advance notice registration as a method for securing the creditor's right [27]. It believes that advance notice registration is a legal method with the effect of real right aiming to preserve the claim on alteration of real property rights, a procedural system in the registration law at best, rather than an independent right. Second is about the theory of quasi property [28], which holds that the right to make advance notice registration is an obligatory right that has the nature of the real right or quasi-property. Since the advance notice registration makes the "claim right" included in the registration have the exclusive effect of the real right, so it is a kind of quasi-property which lies between the creditor's right and the property right and has both natures. Third is about the theory of turning the obligatory right into a real right. Most domestic scholars including Liang Huixing [29], Sun Xianzhong [30], and Fang Shaokun [31] agree that the nature of the advance notice registration is turning the obligatory right into a real right. According to this view, advance notice registration is, essentially, the right of 
obligatory claim and its essential feature is making the registered claim right have the effect of the real right. In other words, the registered claim right can exclude others from disposing of the real property included in the registered claim, ensuring that only the legal effect expected by the registered claim right takes place. All in all, the essential feature of advance notice registration lies in making the claim right have the effect of the real right through registration and guaranteeing this transformation, which actually arouse theoretical disagreements over the nature of advance notice registration. Although the claim right going through advance notice registration has the exclusiveness of the real right and thus make advance notice registration has the publicity method expected by the secured obligatory right, the right registered through advance notice registration is still the obligatory right.

As for the legal effect of the advance notice registration system, there are mainly the "three-effecttheory" and the "four-effect-theory". The "three-effect-theory" [32] refers to the right preservation effect, the sequence preservation effect, and the bankruptcy preservation effect, which applies to the German Law. It is suggested we should follow the German model to clarify the three effects in future legislation of China's Real Right Law and stress that the ineffective "intermediate behavior" ought to be relatively ineffective in the claim right preservation effect. Yang Xuefei, Zhong Wuyi and other scholars support the "four-effect-theory" [33] which includes the right preservation effect, the sequence preservation effect, the bankruptcy preservation effect, and the warning effect. The socalled right preservation effect is the effect of securing the claim right and achieving the specific effect expected; the so-called sequence preservation effect refers to the situation in which the alternation of the property right goes through official registration in sequence as required by the claim right. In other words, advance notice registration enables the claim right exclude later rights to be registered; and the so-called bankruptcy protection effect means that the claim right of advance notice registration can object other creditors when the real property right holder goes bankrupt so that the claim of the advance notice registration can be realized. The warning effect of advance notice registration enables the right of obligatory claim to confront the third party's bona fide objection by registering the publicizing the claim right of certain real property.

This section deals with the effect of advance notice registration in bankruptcy and enforcement procedures. Advance notice registration is a new system introduced in the legislation of China's Real Right Law. The domestic general viewpoint believes that advance notice registration follows the idea of the German Civil Code and that it has the effect of bankruptcy protection. The bankruptcy protection function realized through advance notice registration means that the secured claim right can still be fulfilled legally when the relevant right holder falls into bankruptcy. He Jia further studied the rationality and feasibility of such bankruptcy protection effect [34] and believed that the advance notice registration system had the effect of bankruptcy protection. However, in his opinion, this effect was incomplete and absolute and subject to certain restrictions in the process of reorganization or liquidation. In addition, the administrator should still have the right to request the court to cancel the obligatory rights that damage creditors' interest and undermine fairness, even if they had been registered.

\section{False Registration of Real Estate}

Article 21 of the Real Right Law stipulates: "In case any related party provides false materials for applying for registration and causes damages to any other person, it/he shall assume the liability for compensation. In case any registration organ causes damages to any other person by virtue of any mistake in registration, it shall assume the liability for compensation. The registration organ may, after making the compensation, recover the amount from the person who causes the registration mistake." Therefore, the compensation for registration errors should be borne by the registration agency first, after which the relevant personnel should be held accountable. As for the nature of compensation for the false registration of real estate, existing legal provisions on land registration indicate the registration error should be compensated by the state because the registration agency is in the charge of the government. However, from the relevant provisions of the Property Law, future 
registration agencies may be of administrative or business nature. Therefore, if the registration agency is of business nature or something else, it is believed that the relevant agency should undertake civil compensation.

False registration is only expressed as "errors in the register of real estate" in Article 19 of the Real Right Law, which is not clear enough and causes different interpretation of "errors in the real estate register" among the academic community. Cui Jianyuan and Wang Shengming [35] believed that the errors defined by Article 19 only referred to right errors because the original intention of establishing correction registration was to protect the real rights of the actual right holders by allowing the actual right holders and interested parties to correct the contents of the real estate register according to the real state of rights. In other words, the errors stipulated in this article only referred to matters recorded in the real estate register which were inconsistent with the actual rights. Lu Botao [36] proposed that the errors defined in the article included both the rights and objects that were in consistent with the actual cases. Cheng Xiao [37] believed the errors in the register of real estate described by China's Real Right Law should include both right and non-right errors because Item 1 of Article 19 didn't explicitly limit errors to the ownership and content of rights as the German Civil Code.

As for the nature of the compensation liability for damages caused by false registration of real estate, the academic community has put forward many ideas including the theory of state compensation liability, the theory of civil liability, the theory of dual nature and the theory of unclear responsibility nature. The main reason for Liang Huixing's [38] support for the theory of state compensation liability was that China's real estate registration agency was a state organ and the registration act were a specific administrative act. In other words, the nature of compensation liability for registration errors made by a governmental agency should naturally belong to the state administrative compensation liability. Therefore, the provisions pertaining to administrative compensation of the State Compensation Law shall apply to such errors and the compensation costs shall be paid by the state in a unified manner. Wang Chongmin, Wang Liming [39] and Yang Lixin supported the theory of civil liability mainly because of such a fact: while real estate registration was currently carried out by administrative agencies, the registration of real estate rights was an alternation of civil rights and private law act. Therefore, the compensation liability for false registration of real estate should be positioned as civil liability. The theory of dual nature [40] advocated that real estate registration included two acts, namely, the application for registration made by the civil subject and the review of registration made by the registration agency. Therefore, the compensation liability for damages caused by the former should be civil liability while the liability for damages caused by the latter belonged to the state. The theory of unclear responsibility nature [41] believes that the nature of registration agency of real estate should the further clarified as the administrative management system undergoes reform and that it is not appropriate to stipulate the state compensation liability of the registration agency.

As for the issue concerning the liability forms of the real estate registration agencies and the applicants for registration, there is the theory of proportional liability, the theory of joint liability, theory of individual liability and the theory of supplementary liability. It is [42] thought that the real estate registration agency should bear proportional liability because the third party takes the advantage of registration agency's errors for their own profits. In other words, since the ultimate beneficiary of registration errors is a third party rather than the registration agency, according to the principle of fairness which believes that the degree of negligence and the share of liability should be proportional, the registration agency should bear the liability for compensation conforming to its negligence. Lin Yongkang [43] supported the theory of joint liability and believed that the registration agency and the applicant should bear joint liability. Judging from the composition of the infringement, although the applicant and the registration agency had no subjective communication, their behavior was objectively related and together resulted in the damage. In other words, their objective behavior was linked to joint injury, which belonged to the common act of tort. Therefore, the applicant and the registration agency shall bear joint liability to compensate for victim's damage in one lump sum in the same lawsuit, which was more convenient for the victim to seek legal relief than the supplementary liability method. Yang Lixin believed that the liability form of damages caused by 
registration errors of real estate should be unreal joint liability [44], because the liability form of damages caused by registration errors of real estate was in full compliance with the feature of unreal joint liability. Unreal joint liability means that several liable subjects violate the legal obligations to the same civil subject, and their infringement liability for the same damage fact overlaps. In addition, in the case of overlapped tort liabilities, the victim's right can be relieved if only one tort liability is performed. In addition, unreal joint liability is divided into intermediate liability and final liability. Therefore, in case victim request liability from two responsible parties, the liability that both of the liable parties should bear is intermediate liability while the liability that one party seek from the other is the ultimate responsibility. Wang Liming argued that the liability for damages caused by real estate registration errors was strict liability [45]. Article 21 of the Real Right Law stipulates two kinds of liabilities. First, if the registration applicant provides false materials to apply for registration and causes harm to others, the resulted damage shall be firstly compensated by the applicant; second, if the registration agency does not perform its review obligations, it should also be liable for the harm imposed on the third party.

The doctrine of liability fixation for the compensation liability of the registration agency is not clearly defined in Item 2 of Article 21 of the Real Right Law. Therefore, there appear four main points of view: the theory of fault liability, the theory of presumed fault liability, the theory of no-fault liability, and the theory of dual liability. The first view [46] believes that the liability of the registration agency is in principle a fault liability rather than a strict liability mainly because the liability of the registration agency belongs to a state compensation liability. Besides, according to the general rules of the Tort Liability Law, the liability for damage compensation should be a fault liability. The second view [47] deems that Item 1 of Article 19 of the Real Right Law stipulates the fault liability and Item 2 stipulates the strict liability. The third view believes that the principle of nofault liability applies to the civil compensation liability for false registration done by the registration agency [48]. Since the liability of the registration agency for the false registration done by its staff member belongs to one of the employer responsibilities, namely, vicarious liability. From the legislative spirit of Item 1 of Article 34 of the Tort Liability Law, Employers shall bear tortious liability for any injury or damage caused to other people by their employees in the course of their work; and their liability is not based on fault and thus belongs to the no fault liability.

As for the compensation methods for the false registration of real estate, there are also ideas of establishing compensation fund and insurance for false registration in addition to state compensation. Li Xiaobing [49] believed that the creation of a compensation fund was the best choice for dealing with registration errors. The compensation of real estate registration agencies should be implemented the principle of no-fault liability presumption. As long as the registration agency of real estate causes damage to others because of registration errors, it must compensate the victim for his direct loss in line with the law. Ma Xusheng [50] agreed with the creation of compensation insurance whose mechanism mainly came from the ownership insurance of registration in the US law. In other words, if there is a dispute over ownership and compensation, it will be solved by the insurance company according to law. With the involvement of title insurance companies, real estate transactions become safer and more concise. Taking the insurance mechanism as the main body, the compensation risks caused by registration are generally borne by the entire dangerous "community", supplemented by the state finance, which better realizes the equitable distribution of compensation risks, and will surely provide the most powerful guarantee for the registration credibility system to perform its function.

\section{Conclusion}

The registration system of real estate is at the core of the real estate law, but China has not yet formulated a law of real estate registration. With the acceleration of China's legislative process, the creation of a real estate registration law featuring "unified legal basis, unified registration authority, unified registration validity, unified registration procedures, and unified ownership certificates" has been put on the agenda, and the legislation on real estate is bound to be the emphasis to improve and amend the Real Right Law. The legislation on real estate will center on the following issues: the scope 
of real estate registration such as the establishment and system design of land contract management right and its validity as well as the registration of stratification of construction land-use right; the nature and validity of special registration systems such as correction registration, objection registration, and advance notice registration; and the connotation of registration errors, the nature of damages and liability forms, and doctrine of liability fixation. In addition, the integrated research on the basic theories and specific systems of real estate registration needs to be furthered in order to connect and coordinate different basic systems of real estate registration, which requires systematic and unified theoretical research.

\section{References}

[1]. Long Jun, The Registration Confrontation Doctrine of China's Real Right Law [J]. Chinese Journal of Law, 2012, 34(05): 136-153.

[2]. Guo Zhijing, Also on the Registration Confrontation Doctrine in Chinese Real Right Law [J]. Journal of Comparative Law, 2014(03): 95-113.

[3]. Lu Jian \& Chen Zhentao, Confirming Contracted Management Rights of Rural Land System: Fuzziness and Clarification [J]. Journal of Nanjing Agricultural University (Social Science Edition), 2017, 17(03): 95-102+158.

[4]. Ren Qing'en, The Basis and Form of the Unified Registration System of Real EstateConcurrently Talk about the Revision of The Law of Land Administration and the Formulation of Regulation on Real Estate Registration [J]. China Land, 2014(03): 31-33.

[5]. Long Jun, The Registration Confrontation Doctrine of China's Real Right Law [J]. Chinese Journal of Law, 2012, 34(05): 136-153.

[6]. Nie Jia, Registration of Estates of Contracted Land in China [J]. Modern Law Science, 2008 (04): 187-193.

[7]. Xing Lin, A Preliminary Study of the Effectiveness of Real Right Registration in China's Rural Land Contract Management Right [J]. China Market, 2009 (13): 114-115.

[8]. Shen Weixing, Research on Registration from the Perspective of Property Law [J]. Journal of National Prosecutors College, 2007 (03): 7-18.

[9]. Zhang Shuanggen, Question about the Pre-announcement Registration System in the Pre-sale of Commercial Housing [J]. Tsinghua University Law Journal, 2014, 8 (02): 68-86.

[10]. Chen Xiao, Study of the Registration of the Caution of Hypotheca [J]. Peking University Law Journal, 2017, 29(02):429-455.

[11]. Refer to "The Guaranty Contract Dispute Case between Jinlong Microfinance Co., Ltd. of Datong County, Datong and Taihechun Industrial Co., Ltd. of Datong”, Civil Judgment No. 78 of Shanxi Higher People's Court (20 U).

[12]. Cui Jianyuan, The Real Right: Norms and Doctrines-Centering on the Interpretation of the Chinese Real Right Law (2011), Beijing: Tsinghua University Press, 50.

[13]. Shi Jianhui, Practice Investigation and Legislative Improvement of Construction Land Use Right - Taking Nanjing Metro Construction as an Example [J]. Studies in Law and Business, 2016, 33 (03): 38-45.

[14]. Wang Yanxia, Research on the Question of Law Arising in the Use of the Land Hierachical [J]. Hebei Law Science, 2012, 30 (07): 101-107.

[15]. Huang Zhoubing, Real Right Tendency of Leasehold in China and Its Choice of Publicity Model [J]. Jiangxi Social Sciences, 2009 (08): 183-187. 
[16]. Meng Qinguo, Research on the History Development of the Concept of Possession and China's Possession System [J]. Social Sciences in China, 1993 (04): 75-87.

[17]. Yin Fei \& Fei Jing, On the Conceptual Composition of Correction Registration - the Ninth Discussion on the Housing Registration Method, [J]. China Real Estate, 2009 (01): 23-26.

[18]. Wang Liming, Research on the Real Right Law (2007), Beijing: China Renmin University Press, 332.

[19]. Shen Huiwen, On the Claim for Registration Corrections Centered on the first paragraph article 19 of Chinese Property Law [J]. Journal of Heilongjiang Administrative Cadre Institute of Politics and Law, 2014 (02): 128-131.

[20]. Chen Xiao, On Ex Officio Registration [J]. China Real Estate, 2011(19):29-32.

[21]. Yin Fei, The Nature and Development of Real Estate Registration-Also on the Improvement of the Real Estate Registration System When Compiling the Civil Code [J]. Tsinghua University Law Journal, 2018, 12 (02): 43-58.

[22]. Chen Ye, Stakeholders in Real Estate Right Registration [J]. China Real Estate, 2013 (17): 26-28.

[23]. Sun Xianzhong, Draft Proposal on Real Estate Registration Bill (2014), Beijing: China Social Sciences Press, 140.

[24]. Sun Xianzhong, A General Introduction to China's Real Right Law (2014), Beijing: Law Press China, 392.

[25]. Chang Pengao, Law of Real Estate Registration (2011), Beijing: Social Sciences Academic Press, 199.

[26]. Yu Haiyong, Research on the Legislation of Unified Registration of Real Estate (2016), Beijing: Law Press China, 204.

[27]. Li Wei, Research on Several Issues Concerning the System of Real Estate Notice Registration [J]. Reformation \& Strategy, 2007 (08): 150-153.

[28]. Wang Liming, On the Law of Real Right (2003), Beijing: China University of Political Science and Law Press, 172.

[29]. Liang Huixing, Recommendations for the Draft of the Chinese Civil Code (Real Right) (2004), Beijing: Law Press China, 38.

[30]. Sun Xianzhong, On the Real Right Law (2001), Beijing: Law Press China, 454.

[31]. Fang Shaokun \& Lv Jie, Several Issues in Formulating the System of Advance Notice Registration [J]. Jurists Review, 2003 (04): 63-71.

[32]. Item 2 and Item 3 of Article 883 of the German Civil Code. Article 24 of the German Insolvency Act.

[33]. Yang Xuefei, The Comparative Research of Registration of Caution [J]. Hebei Law Science, 2006 (11):179-186.

[34]. He Jia, On the Effect of Bankruptcy Protection for Real Estate Advance Registration [J]. Zhejiang Academic Journal, 2014 (05): 156-162.

[35]. Cui Jianyuan, Real Right Law (2011), p.57, Beijing: China Renmin University Press. Wang Shengming, Interpretation of China's Real Right Law (2007), Beijing: China Legal System Publishing House. p.50. 
[36]. Lv Botao, Research on Major Difficulties in the Application of the Real Right Law (2008), Beijing: People's Court Press. p.42.

[37]. Chen Xiao, Types of the Falsity of Real Estate Register and Registration of Rectification [J]. Science of Law (Journal of Northwest University of Political Science and Law), 2011, 29(04): 164-174.

[38]. Liang Huixing, Proposal for the Draft of the Real Right Law of China Accompanied with Reason, Beijing: Social Sciences Academic Press, 2007, p.125.

[39]. Wang Chongmin, Discussion on Compensation Liability of China's Real Estate Registration Authorities [J]. Journal of Henan Administrative Institute of Politics and Law, 2007 (05): 198201. Wang Liming, Research on the Real Right Law (Volume 1), Beijing: China Renmin University Press, 2007, p.367.

[40]. Yuan Yonghong, On the Liability of Registration Errors of Real Estate Registration Agencies [J]. Shandong Social Sciences, 2009 (07): 133-135.

[41]. Civil Affairs Office of the Legal Affairs Committee of NPC Standing Committee: Statement, Legislative Reasons and Related Provisions of Provisions of China's Real Right Law, Beijing: Peking University Press, 2007, p.16.

[42]. Zhao Daguang \& Yang Linping \& Wang Zhenyu, Understanding and Application of the "Regulations on Several Issues Concerning the Trial of Housing Registration Cases" [J]. People's Judicature, 2010 (23): 31-38.

[43]. Lin Yongkang \& Lan Ge, Discussion on the Liability for Damages Caused by Real Estate Registration Errors [J]. Fujian Law Journal, 2007 (04): 51-54.

[44]. Yang Lixin, On the Nature of the Compensation Liability for Damages Caused by Real Estate Registration Errors [J]. Contemporary Law Review, 2010, 24 (01): 4-12.

[45]. Wang Liming, The Implementation of the Real Right Law and the Improvement of Supporting Laws and Regulations, Introduction to Chinese Real Right Law (2007), p.123.

[46]. Yang Lixin, On the Nature of the Compensation Liability for Damages Caused by Real Estate Registration Errors [J]. Contemporary Law Review, 2010, 24 (01): 4-12. Wang Yi, Interpretation and Application of the Real Right Law, Beijing: People's Publishing House, 2007, p. 50 .

[47]. Wang Liming, Introduction to Chinese Real Right Law, Beijing: People's Court Press, 2007, p. 122 .

[48]. Liu Baoyu, The Nature and Form of Liability for Damage from Mistakes of Real Estate Registration Agencies, [J]. China Legal Science, 2012 (02): 156-169.

[49]. Li Xiaobing, Compensation Fund: The Best Way to Compensate for Registration Errors [N]. The Chinese Newspaper of Land and Resources, 2014-08-15 (05):89-93.

[50]. Ma Xusheng, Compensation Mechanism to Registration: Analysis from the Perspective of Public Reliance Effect [J]. Jinan Journal (Philosophy \& Social Science Edition), 2006 (05): 177178. 